\title{
Impact of nutrition on serum percentage in heifers
}

This article was published in the following Dove Press journal:

Open Access Animal Physiology

18 August 2010

Number of times this article has been viewed

\author{
S Begum' \\ MMR Howlader' \\ MS Islam' \\ MA lqbal ${ }^{2}$ \\ 'Department of Physiology and \\ Pharmacology, Faculty of Veterinary \\ Medicine and Animal Science, Sylhet \\ Agricultural University, Tilagar, Sylhet; \\ ${ }^{2}$ Aftab Bahumukhi Farms Ltd, Bajitpur, \\ Kishoregonj, Bangladesh
}

Correspondence: S Begum

Department of Physiology and Pharmacology, Faculty of Veterinary Medicine and Animal Science, Sylhet Agricultural University, Tilagar, Sylhet, Bangladesh

Tel + 880 I7I 2639013

$\mathrm{Fax}+880821761980$

Email begumbd78@yahoo.com
Abstract: The aim of this study was to determine the impact of nutrition on serum percentage of blood in crossbred heifers. The animals were grouped into four, and allocated to one of three groups, ie, $\mathrm{T}_{0}$, a control group fed on $8 \mathrm{~kg}$ /day of green grass and $3 \mathrm{~kg} /$ day of concentrates, or a $\mathrm{T}_{1}$ or a $\mathrm{T}_{2}$ group fed on $40 \%$ (4.8 $\mathrm{kg}$ /day green grass and $1.8 \mathrm{~kg} /$ day concentrate per animal) and $60 \%(3.2 \mathrm{~kg} /$ day green grass and $1.2 \mathrm{~kg} /$ day concentrate per animal) restricted feeding. Blood samples were collected on the first day of treatment and then at three-day intervals for 63 days. Serum percentage increased significantly $(P<0.05)$ in Groups $\mathrm{T}_{1}$ (by $49.1 \%$ ) and $\mathrm{T}_{2}$ (by $56.5 \%$ ) compared with $\mathrm{T}_{0}$ (by $41.5 \%$ ). Significant $(P<0.01)$ decreases were found in total erythrocyte count (by 5.6 and $4.2 \mathrm{~g} \%$ ), hemoglobin content (by 8.0 and $6.5 \mathrm{~g} \%$ ), and packed cell volume (by $31.4 \%$ and $22.9 \%$ ) in Groups $\mathrm{T}_{1}$ and $\mathrm{T}_{2}$, respectively, compared with $\mathrm{T}_{0}$. It is suggested that the amount of feed given daily is important in maintaining the standard blood cell and serum percentage levels considered indicative of general good health in animals.

Keywords: restricted feeding, crossbred heifers, feeds, serum percentage

\section{Introduction}

Nutritional deficiency is a common cause of poor livestock production. Vitamins and minerals are essential for the building of tissues and disease resistance, as well as maintenance of the musculoskeletal system and other soft tissues in the body. ${ }^{1}$ All vitamins and minerals are obtained from a balanced diet, but only a few are required for musculoskeletal development, in addition to the ones essential for the constituents of blood, especially copper, cobalt, and iron. ${ }^{2} \mathrm{~A}$ balanced diet is essential for adequate blood cell production, and requires adequate quantities of protein, iron, copper, cobalt, and vitamins, particularly those of the $\mathrm{B}$ complex series, including riboflavin $\left(\mathrm{B}_{2}\right)$, pyridoxine $\left(\mathrm{B}_{6}\right)$, folic acid, thiamin $\left(\mathrm{B}_{1}\right)$, and cyanocobalamin $\left(\mathrm{B}_{12}\right)$. Much research on the supplementation of nutrition with different hematological parameters has been performed elsewhere. ${ }^{3}$ However, very limited research has been done to investigate the serum percentage of whole blood using restricted feeding in heifers in Bangladesh. This study was done to determine the effect of nutrition on serum percentage following standard and restricted feeding and to determine the standard level of nutrition required to maintain a standard blood serum percentage in crossbred cattle.

\section{Materials and methods} \section{Animals and management}

The work was conducted using 12 healthy cyclic Holstein $\times$ Friesian crossbred heifers of $\mathrm{F}_{1}, \mathrm{~F}_{2}$, or $\mathrm{F}_{3}$ generation, aged 3.0-4.0 years, from the Sylhet Government 
Table I Standard concentrate feed used in the experiment

\begin{tabular}{llll}
\hline SL & Feed ingredients & Quantity (g) & Composition (\%) \\
\hline I. & Corn & 750 & 25 \\
2. & Wheat bran & 600 & 20 \\
3. & Rice polish & 450 & 15 \\
4. & Khesari & 600 & 20 \\
5. & Soya bean meal & 510 & 17 \\
6 & Dicalcium phosphate & 60 & 2 \\
7. & Salt & 30 & 1 \\
& Total & 3000 & 100 \\
\hline
\end{tabular}

Dairy farm. A uniform group of 12 heifers was selected randomly, reared under farm conditions, and provided with green grass $8 \mathrm{~kg}$ /day and $3 \mathrm{~kg} /$ day concentrate (see Table 1 for composition) per heifer for the first three months. All animals were treated fortnightly with four concurrent doses of levamisole $7.7 \mathrm{mg} / \mathrm{kg}$, albendazole $7.5 \mathrm{mg} / \mathrm{kg}$, fenbendazole $10 \mathrm{mg} / \mathrm{kg}$, and piperazine citrate $0.3 \mathrm{~g} / \mathrm{kg}$ for strategic parasite control. After three months, the animals were divided into three groups, ie, $\mathrm{T}_{0}$ (control), $\mathrm{T}_{1}$, and $\mathrm{T}_{2}$.

Equal amounts of Napier (Pennisetum purpureum) and Para grasses (Brachiaria mutica), ie, $3.5 \mathrm{~kg} / 100 \mathrm{~kg}$, were fed to satisfy the dry matter requirement of the animals. A mixture of concentrates, $3 \mathrm{~kg} /$ day per animal were given as standard feed to the control group $\mathrm{T}_{0}{ }^{4}$ Groups $\mathrm{T}_{1}$ and $\mathrm{T}_{2}$ were fed $40 \%$ and $60 \%$ less than the standard feeding requirement, respectively. The daily amounts of feed given to the animals in the $\mathrm{T}_{0}, \mathrm{~T}_{1}$, and $\mathrm{T}_{2}$ groups were $8 \mathrm{~kg}$ green grass and $3.0 \mathrm{~kg}$ concentrate, $4.8 \mathrm{~kg}$ green grass and $1.8 \mathrm{~kg}$ concentrate, and $3.2 \mathrm{~kg}$ green grass and $1.2 \mathrm{~kg}$ concentrate per animal, respectively. Water was made available to each animal at all times in a separate manger.

\section{Blood sampling}

For the hematologic examination, $5-10 \mathrm{~mL}$ blood samples were collected aseptically from the jugular vein using a sterile syringe and needle from all animals, and transferred immediately to separate clean, dried glass vials without anticoagulant for serum at three-day intervals for 21 days. Approximately $5-6 \mathrm{~mL}$ of blood was also transferred immediately to separate clean, dried glass vials containing ethylenediaminetetraacetic acid $0.2 \mathrm{mg} / \mathrm{mL}$. The hematologic studies were performed within five hours of collection of the blood samples, as described by Lamberg and Rothstein. ${ }^{7}$

\section{Blood serum ratio}

The tubes containing the blood samples were placed in a tilted position at room temperature for six hours and then stored in a refrigerator at $4-8^{\circ} \mathrm{C}$ overnight. The serum samples were separated after 24-36 hours and centrifuged. Following separation, the amount of serum was measured with the help of a measuring pipette to calculate the blood: serum ratio. All the procedures were performed within 48 hours of blood collection as described by Lamberg and Rothestein. ${ }^{7}$ The data obtained were statistically analyzed by logistic regression using statistical software program STATA 8.0 (Stata Corp, College Station, TX).

\section{Results and discussion}

The impact of nutrition on serum percentage was evaluated in the heifers and the results are presented in Table 2 and Figure 1. Serum percentages were $41.5 \%, 49.1 \%$, and 56.5\%, and blood: serum ratios were 2.3:1, 2.1:1, and 1.8:1, respectively, for Groups $\mathrm{T}_{0}, \mathrm{~T}_{1}$, and $\mathrm{T}_{2}$ (see Table 2 and Figure 1). The serum percentage of blood increased in Groups $\mathrm{T}_{1}$ and $\mathrm{T}_{2}$ compared with Group $\mathrm{T}_{0}$. Blood: serum ratios and serum percentages were significantly $(P<0.01)$ higher in Groups $\mathrm{T}_{1}$ and $\mathrm{T}_{2}$ compared with Group $\mathrm{T}_{0}$. Serum percentage of blood depends entirely on the blood cell, plasma protein, and enzyme content in blood. In the present study, the standard serum percentage was found in the control group $\left(\mathrm{T}_{0}\right)$ due to prescribed feeding, and the highest serum percentage was found in the malnutrition group $\left(\mathrm{T}_{2}\right)$.

The results of hematologic parameters are presented in Table 3. The mean values of hemoglobin ( $\mathrm{Hb})$, packed cell volume (PCV), and total erythrocyte count (TEC) were $9.9 \mathrm{~g} \%, 8.0 \mathrm{~g} \%$, and $6.5 \mathrm{~g} \% 35.6 \%, 31.4 \%$, and $23.0 \%$, and 7.2, 5.6, and 4.2 million $/ \mathrm{mm}^{3}$ of blood for Groups $\mathrm{T}_{0}, \mathrm{~T}_{1}$,

Table 2 Effects of nutrition on the blood serum ratio in experimental crossbred heifers

\begin{tabular}{|c|c|c|c|c|c|c|c|c|c|}
\hline \multirow[t]{2}{*}{ Parameter } & \multicolumn{3}{|l|}{$T_{0}$} & \multicolumn{3}{|l|}{$\mathbf{T}_{1}$} & \multicolumn{3}{|l|}{$\mathbf{T}_{2}$} \\
\hline & Mean \pm SE & $P$ value & $\%$ & Mean \pm SE & $P$ value & $\%$ & Mean \pm SE & $P$ value & $\%$ \\
\hline BSR & $2.3 \pm 0.1: 1$ & 0.0 & 41.5 & $2.1^{* *} \pm 0.1: 1$ & 0.00 & 49.1 & $1.8^{* *} \pm 0.16: 1$ & 0.0 & 56.5 \\
\hline
\end{tabular}

Note: $* * P<0.01$.

Abbreviations: BSR, blood serum ratio; SE, standard error. 


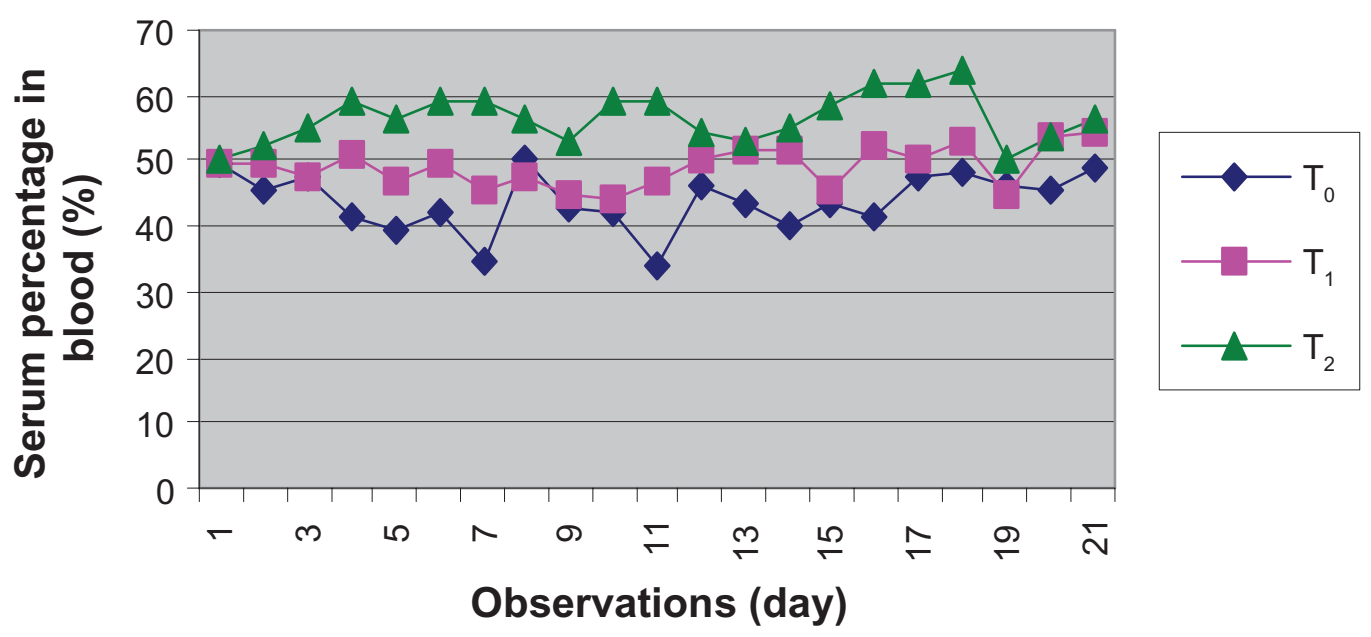

Figure I The values of blood serum percentage at different observations in crossbred heifers $(n=4)$.

and $\mathrm{T}_{2}$, respectively. $\mathrm{Hb}, \mathrm{PCV}$, and TEC content decreased significantly $(P<0.01)$ in Groups $\mathrm{T}_{1}$ and $\mathrm{T}_{2}$ compared with Group $\mathrm{T}_{0}$. Standard feeding therefore increased hematologic values and restricted feeding decreased these values significantly. This result is partially in agreement with the findings of $\mathrm{Ali},{ }^{5}$ who reported a significant increase in TEC, $\mathrm{Hb}$, and $\mathrm{PCV}$ in all groups while describing a similar effect of minerals (iron, copper, and cobalt) in goats. The $\mathrm{Hb}$ concentrations found in this study are in agreement with the report of Sumati and Kapoor, who reported increased $\mathrm{Hb}$ values following dietary iron supplementation in Wistar rats. ${ }^{8}$ The report of Wenzlaf and Erhardt of $\mathrm{Hb}$ and $\mathrm{PCV}$ concentrations following parenteral administration of iron dextran to lambs showed higher values, which are in part similar to our findings. ${ }^{9}$ Our results are in agreement with those of Bausted and Tollersrud who observed an increased value of TEC, Hb, and PCV following intramuscular administration of cobalt and iron dextran to calves. ${ }^{6}$ All of those experiments were done in rats and goats. However, in our study, the treatments were given to heifers.
Serum percentage was inversely correlated with PCV, which represents the cellular (red blood cell) portion of blood. Increased PCV levels were correlated with a decreased serum percentage. This result is partially consistent with the findings of Ali, who recorded a significant increase in TEC, $\mathrm{Hb}$, and PCV in all groups when comparisons were made, along with iron, copper, and cobalt supplementation in goats. ${ }^{5}$

\section{Summary and conclusion}

This study was carried out to investigate the effects of nutrition on the serum percentage of blood in crossbred heifers. Under the conditions described here, it is concluded that standard feeding with proper nutrition is helpful for maintaining a normal ratio of blood cells and serum percentage, which helps to achieve maximum performance in crossbred cattle.

\section{Disclosure}

The authors report no conflict of interest in this work.

Table 3 Effects of nutrition on hematologic parameters in crossbred heifers ( $n=4$ per group)

\begin{tabular}{|c|c|c|c|c|c|c|}
\hline \multirow[t]{2}{*}{ Parameters } & \multicolumn{2}{|l|}{$\underline{T}_{0}$} & \multicolumn{2}{|l|}{$\mathbf{T}_{1}$} & \multicolumn{2}{|l|}{$\underline{\mathbf{T}_{2}}$} \\
\hline & Mean \pm SE & $\begin{array}{l}P \text { value } \\
(P>t)\end{array}$ & Mean \pm SE & $\begin{array}{l}P \text { value } \\
(P>t)\end{array}$ & Mean \pm SE & $\begin{array}{l}P \text { value } \\
(P>t)\end{array}$ \\
\hline $\mathrm{Hb}(\mathrm{gm} \%)$ & $9.9 \pm 0.1$ & 0.00 & $8.0 * * \pm 0.2$ & 0.000 & $6.5^{* *} \pm 0.2$ & 0.00 \\
\hline PCV (\%) & $35.6 \pm 0.4$ & 0.000 & $31.4^{* *} \pm 0.6$ & 0.000 & $22.9 * * \pm 0.6$ & 0.000 \\
\hline TEC (million/ $\mathrm{cm}^{3}$ ) & $7.2 \pm 0.2$ & 0.00 & $5.6 * \pm 0.3$ & 0.001 & $4.2^{* *} \pm 0.3$ & 0.00 \\
\hline
\end{tabular}

Notes: $* p<0.05 ; * * p<0.01$.

Abbreviations: Hb, hemoglobin; PCV, packed cell volume; TEC, total erythrocyte count; SE, standard error. 


\section{References}

1. Geneser F. Textbook of Histology. 1st ed. Copenhagen, Denmark: Munksgaard; 1986.

2. Lind F, Blum JW. Growth performance hematological traits, meat variables and effects of treadmill and transport stress in veal calves supplied different amounts of iron. Journal of Veterinary Medicine, Series A. 1994;41:333-342.

3. Ismail D. The effect of cobalt, copper and mineral lick supplementation on calves grazing on pasture. Mardi Res Bull. 1983;11:21-29.

4. Banerjee GC. A Text Book of Animal Husbandry. 8th ed. New Delhi, India: Oxford and IBH Publishing Company; 1998.

5. Ali $\mathrm{MH}$. A comparative study of haematinics $(\mathrm{Fe}, \mathrm{Cu}, \mathrm{Co})$ in goats. Dissertation. Department of Physiology, Faculty of Veterinary Medicine, Bangladesh Agricultural University, Mymensing, Bangladesh; 1992.
6. Baustad B, Tollersrud S. Experiment with injection of cobalt and iron dextran in calves. Medlemsbl Norske Vet Foren. 1996;18: 419-423.

7. Lamberg SL, Rothestein R. Laboratory Manual of Hematology and Urinalysis. 1st ed. Westport, CT: AVI Publishing Company, Inc.; 1977.

8. Sumati W, Kapoor AC. Influence of dietary iron on growth and hemoglobin concentration. Indian Journal of Nutrition and Diabetes. 1986;23:257-261.

9. Wenzlaf O, Erhardt G. Effect of parentally administered iron dextran on erythrocyte parameters and growth rate in lambs of different breeds. Berlier Munchener Tierarzt Liche Wochen Schrift. 1991;103: 239-244.

\section{Publish your work in this journal}

Open Access Animal Physiology is an international, peer-reviewed, open access journal publishing original research, reports, reviews and commentaries on all areas of animal physiology. The manu-

quick and fair peer-review system. Visit http://www.dovepress.com/ testimonials.php to read real quotes from published authors. 